\title{
Medical English and Spanish cognates: identification and classification
}

Lourdes Divasson and Isabel León

\section{(2) OpenEdition}

12 Journals

\section{Electronic version}

URL: http://journals.openedition.org/asp/1607

DOI: 10.4000/asp.1607

ISBN: 978-2-8218-0388-6

ISSN: 2108-6354

\section{Publisher}

Groupe d'étude et de recherche en anglais de spécialité

\section{Printed version}

Date of publication: 1 December 2002

Number of pages: $73-87$

ISSN: 1246-8185

\section{Electronic reference}

Lourdes Divasson and Isabel León, « Medical English and Spanish cognates: identification and classification », ASp [Online], 35-36 | 2002, Online since 17 August 2010, connection on 19 April 2019. URL : http://journals.openedition.org/asp/1607 ; DOI : 10.4000/asp.1607

This text was automatically generated on 19 April 2019

Tous droits réservés 


\title{
Medical English and Spanish cognates: identification and classification
}

\author{
Lourdes Divasson and Isabel León
}

\section{Introduction}

1 "False cognate" or "false friend" are metalinguistic terms used to name "a word which has the same or very similar form in two languages, but which has a different meaning in each". (Platt, Richards \& Weber 1985: 103). In a written text, it is the orthographical identity or similarity that can lead a second language learner to use the word wrongly, but when it comes to an oral text, a foreign word may sound familiar to us because of its phonological resemblance to a word in our mother tongue.

2 The expression faux amis was used for the first time by Maxime Koessler and Jules Derocquigny in their work Les Faux Amis ou les trahisons du vocabulaire anglais in 1928 (Mounin et al. 1974: 139). Robert and Collins (1990: 296a) refer to these pitfalls as "deceptive cognates". Other coinages for this lexical phenomenon are faux frères, mots sosies and falschen Freunde, among others. Anglophone linguists frequently use the term "false friend", a calque from French, and there are purists that refer to them as "false cognates". In Spanish the expressions falsos amigos and términos equívocos (Cuenca 1987) or palabras de traducción engañosa (Navarro \& Hernández 1992, 1994) are generally used indistinctly.

3 Several scholars have classified these word pairs differently (Larson 1989, Laufer 1990, Moss 1992, Gläser 1995, Maillot 1997), although a distinction between "total" false friends and "partial" ones has been made. In this regard, we adopted here the definitions and classification on semantic criteria offered by R. Gläser in 1995 that establishes three categories of deceptive cognates: 
Total false friends are interlingual word pairs with morphological similarity or even identity, but with a completely different meaning [...].

Partial false friends usually cover two subgroups:

1. interlingual word pairs with identical [or similar, we believe] morphological structure, but only a partial correspondence of their meaning.

2. intralingual word pairs which share the same [or similar] morphological structure, but have different terminological meanings in different subject areas or even within the same subject area. The polysemy [...] is discarded in the textual environment [...]. (Gläser 1995: 17).

4 Examples of these different false friend types (with the misleading cognate capitalized) are given in Table A - Total false friends (hereafter T or TFF), Table B - Partial 1 false friends (hereafter P1 or P1FF) and Table C - Partial 2 false friends (hereafter P2 or P2FF).

Table A. Total false friends

\begin{tabular}{|l|l|l|l|}
\hline English & Spanish & while Spanish & English \\
\hline carbon & carbono & CARBÓN & coal \\
\hline embarrassed & turbado, avergonzado & EMBARAZADA & pregnant \\
\hline carbuncle & ántrax & CARBUNCO & anthrax \\
\hline
\end{tabular}

Table B. Partial 1 false friends

\begin{tabular}{|l|l|}
\hline English & Spanish \\
\hline drug & DROGA / fármaco \\
\hline to retract & RETRACTARSE / retraer, retirar, replegar \\
\hline to divert & DIVERTIR / desviar \\
\hline
\end{tabular}

Table C. Partial 2 false friends

\begin{tabular}{|l|l|}
\hline English & Spanish \\
\hline marked difference & NOTABLE ... \\
\hline marked improvement & NOTORIA ... \\
\hline marked accent & $\ldots$..FUERTE \\
\hline marked contrast & $\ldots$ MAYOR, or ... MÁS ACUSADO \\
\hline a marked man & $\ldots$ FICHADO \\
\hline
\end{tabular}


In Table C "marked" is likely to be translated as marcado/a by the inexperienced reader who does not know of the polysemy of the cognate; thus, the wide variety of lexical equivalences/ alternatives (capitalized in the examples) provided by the dictionary.

The same holds true for the term control (see Table 8). As so aptly stated by Navarro,

en el inglés médico se abusa hasta la saciedad del galicismo 'control' [...]. Si recurrimos a la traducción control cada vez que en inglés se utiliza esta palabra estaremos empobreciendo nuestro idioma hasta límites insospechados". (2000: 110)

Most FF are of Greek or Latin origin and although these word pairs may share identical or very similar spelling in English and Spanish, for some reason, they have acquired different meanings in the two languages:

"ability" means talent, faculty, power in English while

"habilidad" means skill or cleverness in Spanish

"sensible" means wise, aware, appreciative in English while

"sensible" means sensitive in Spanish

8 On the other hand, certain words from extractions other than Greek or Latin have evolved to orthographical forms similar or very close to Spanish lexemes. For instance, the term gripe (Cuenca 1987) derived from old English gripan (to hold) is likely to be translated into Spanish as gripe (influenza).

9 A number of researchers have approached the discussion of these word pairs in English and Spanish general language vocabulary from different aspects: Hill (1982) and Cuenca (1987) with reference to lexicography; Moss (1992) and Lerchundi \& Moreno (1999) focused on the importance of cognate recognition in teaching ESP reading courses to Spanish speakers. Several authors have also dealt with this lexical phenomenon with regard to English for Medical Purposes (EMP): Mackin \& Weinberger (1970), Smith Kline \& French Sae (1979), Navarro \& Hernández $(1992,1993)$, Congost (1994), Divasson (1997) and Navarro (2000), among others. The Diccionario enciclopédico University de términos médicos (1981) also offers a list of FF in medical contexts.

10 Nevertheless, research in contrastive studies so far has focused mainly on General English, one of the exceptions being Gläser's in 1995 on false friends in English and German in LSP vocabulary with special reference to foreign language teaching. She stated that deceptive cognates are also important, "often more intriguing in LSP lexicology" (Gläser 1995: X-xi). But we do not know of any contrastive English-Spanish study dealing comprehensively and systematically with this lexical phenomenon in the field of ME. This paper is thus devoted to the study of deceptive cognates in today's ME written discourse.

\section{Corpus and objective}

11 We gathered a sample that can be considered representative of current ME prose, consisting of twenty research papers, published between 1994 and 1996 in various leading medical journals (The New England Journal of Medicine, The Lancet, Journal of the American Medical Association, etc.), and pertaining to twenty major specialties (for the list of references, see Appendix 1). The corpus is made up of 89,688 running words. This research is part of a wider project carried out at the University of la Laguna, Tenerife, which studies FF in the four ME genres (Editorials, Review Papers, Articles, Research Papers and Case Reports). 
The objectives of this paper are threefold:

- To identify the false friends present in the corpus.

- To classify them as TFF or partial, and within the latter category as P1FF and P2FF.

- To determine the word classes they belong to as well as their ranking.

Our final aim is to elaborate a list of deceptive cognates which could serve in EMP courses and in the training of translators.

\section{Method}

13 Our analysis is limited to the orthographical properties of the interlingual word pairs that cause interference. Over the years we have gathered an ever increasing list which we use as a Reference List of FF. Most of them became evident in the classroom situation with medical students and postgraduates in Medicine, or when correcting exams. Others have been collected from dictionaries of false cognates in General English (Hill 1982, Cuenca 1987), Medical English dictionaries (Stedman Bilingüe 1999), the above mentioned works of Mackin \& Weinberger (1970), Navarro \& Hernández (1992, 1994) and Navarro (2000), among others.

In this article every item of our compiled reference list of FF is considered a lexeme, that is, a word which has an entry in the dictionary. Their multiple inflected or case forms in the corpus are referred to as occurrences.

Every FF from our reference list has been identified by means of a contextual analysis. Their frequency was recorded and their percentages with regard to the total number of running words were computed. The deceptive cognates found were classified according to two groups of variables: the three FF types (T, P1 and P2) and the four main word classes (the so-called full, lexical or content words) - nouns, verbs, adjectives and adverbs. TFF were easily identified. Conversely, P1/P2FF were difficult to differentiate and we have encountered many borderline cases which have not been included in our analysis.

\section{Results}

Table 1. Results: Final number of FF (lexemes and occurrences)

\begin{tabular}{|l|ll|l|}
\hline & $\begin{array}{l}\text { TOTAL NUMBER OF FALSE } \\
\text { FRIENDS (FF) }\end{array}$ & $\begin{array}{l}\text { TOTAL NUMBER } \\
\text { OCCURRENCES (OCC.) }\end{array}$ & OF THEIR \\
\hline TOTAL (T) & $73(18.86 \%)$ & $982(20.50 \%)$ \\
\hline $\begin{array}{l}\text { PARTIAL } \\
\text { (P1) }\end{array}$ & $62(16.02 \%)$ & $730(15.24 \%)$ \\
\hline $\begin{array}{l}\text { PARTIAL } \\
\text { (P2) }\end{array}$ & $252(65.11 \%)$ & $3,077(64.25 \%)$ \\
\hline $\begin{array}{l}\text { FINAL } \\
\text { NUMBER }\end{array}$ & $387(100 \%)$ & $4,789(100 \%)$ \\
\hline
\end{tabular}


Figure 1. Final number of FF (lexemes and occurrences) distributed in types

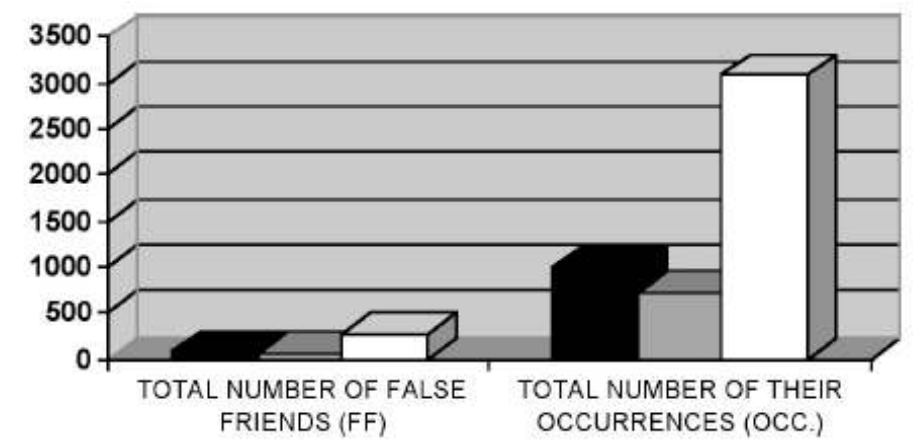

Table 2. Results: Final number of FF (lexemes and occurrences) distributed in word classes

\begin{tabular}{|l|l|l|l|}
\hline & $\begin{array}{l}\text { TOTAL NUMBER OF FALSE } \\
\text { FRIENDS (FF) }\end{array}$ & $\begin{array}{l}\text { TOTAL NUMBER OF THEIR } \\
\text { OCCURRENCES (OCC.) }\end{array}$ \\
\hline NOUNS & $92(23.77 \%)$ & $814(16.99 \%)$ \\
\hline ADJECTIVES & $182(47.02 \%)$ & $2,873(59.99 \%)$ \\
\hline VERBS & $96(24.80 \%)$ & $1,053(21.98 \%)$ \\
\hline ADVERBS & $17(4.39 \%)$ & $49(1.02 \%)$ \\
\hline FINAL \\
NUMBER & $387(100 \%)$ & $4,789(100 \%)$ \\
\hline
\end{tabular}

Figure 2. Final number of FF (lexemes and occurrences) distributed in word classes

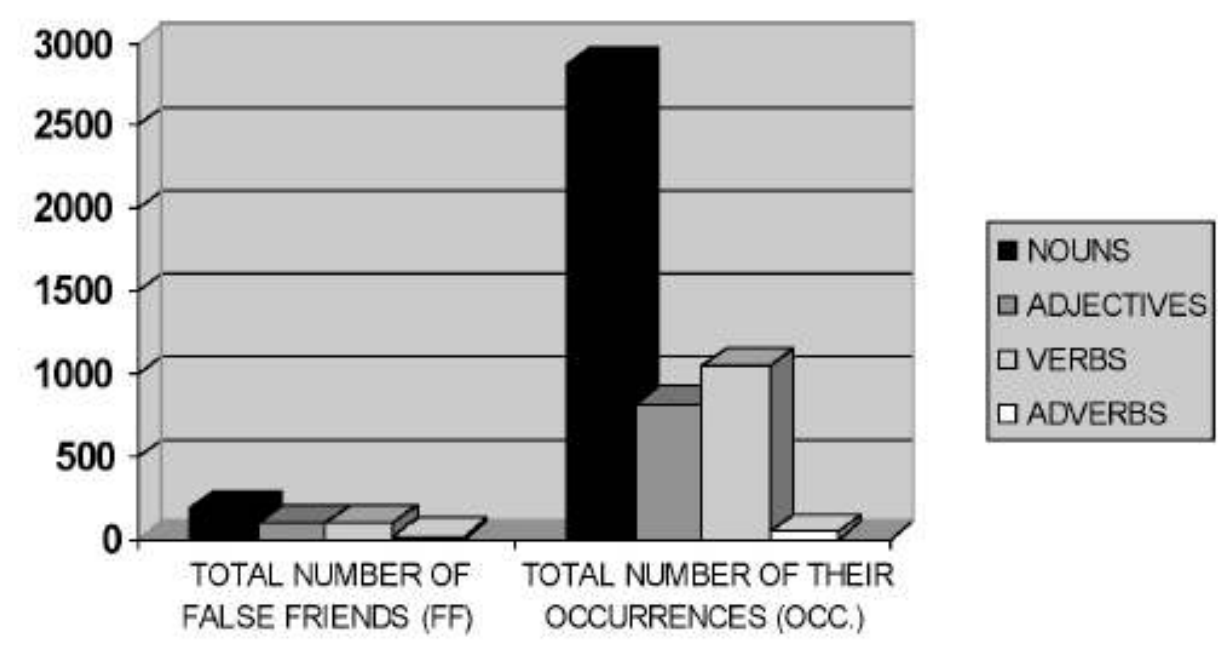

16 There were three times as many P2FF as TFF, and four times as many P2FF as P1FF (see Table 1 and Figure 1). Besides, the total number of noun occurrences was three times more than that of adjectives and verbs and almost 60 times more than that of adverbs (see Table 2 and Figure 2). 
Table 3. Overall percentage of $\mathrm{T}, \mathrm{P} 1$ and $\mathrm{P} 2 \mathrm{FF}$ occurrences with respect to the total number of running words in the corpus

\begin{tabular}{|l|l|}
\hline CORPUS SIZE (running words) & FALSE FRIENDS (occurrences) \\
\hline 89,688 & 4,789 \\
\hline $100 \%$ & $5.339 \%$ \\
\hline
\end{tabular}

Figure 3. Overall percentage of $\mathrm{T}, \mathrm{P} 1$ and $\mathrm{P} 2 \mathrm{FF}$ occurrences with respect to the total number of running words in the corpus

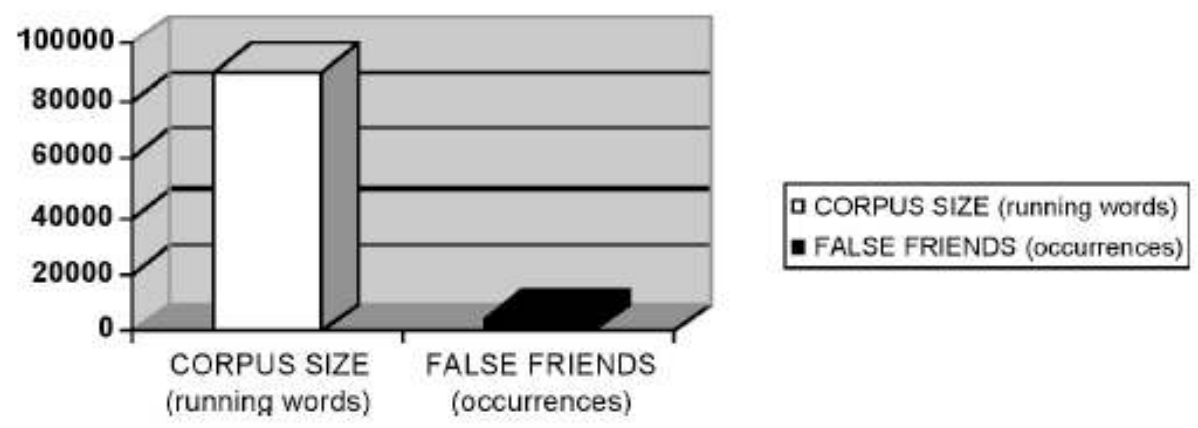

17 Table 3 and Figure 3 illustrate that the 387 FF lexemes gave 4,789 occurrences in the 89,688 running words. The proportion of those occurrences in the biomedical corpus then reached 5.3\%. One can thus infer that in a 6,000-word-research paper (the length of about half of those analysed in our corpus), a reader may encounter about $318 \mathrm{FF}$ forms, or an average of 159 if the article were 3,000 words long, which means more than five deceptive cognates in every 100 running words of text). This may imply a considerable risk of misinterpretation of the original article.

Table 4. Distribution of FF types in word classes (number of lexemes)

\begin{tabular}{|l|l|l|l|l|}
\hline FF & Nouns & Adjectives & Verbs & Adverbs \\
\hline T & $44(24.17 \%)$ & $17(18.47 \%)$ & $8(8.33 \%)$ & $4(23.52 \%)$ \\
\hline P1 & $33(18.13 \%)$ & $14(15.21 \%)$ & $13(13.54 \%)$ & $2(11.76 \%)$ \\
\hline P2 & $105(57.69 \%)$ & $61(66.30 \%)$ & $75(78.12 \%)$ & $11(6470 \%)$ \\
\hline FINAL NUMBER & $182(100 \%)$ & $92(100 \%)$ & $96(100 \%)$ & $17(100 \%)$ \\
\hline
\end{tabular}


Figure 4. Distribution of FF types in word classes (number of lexemes)

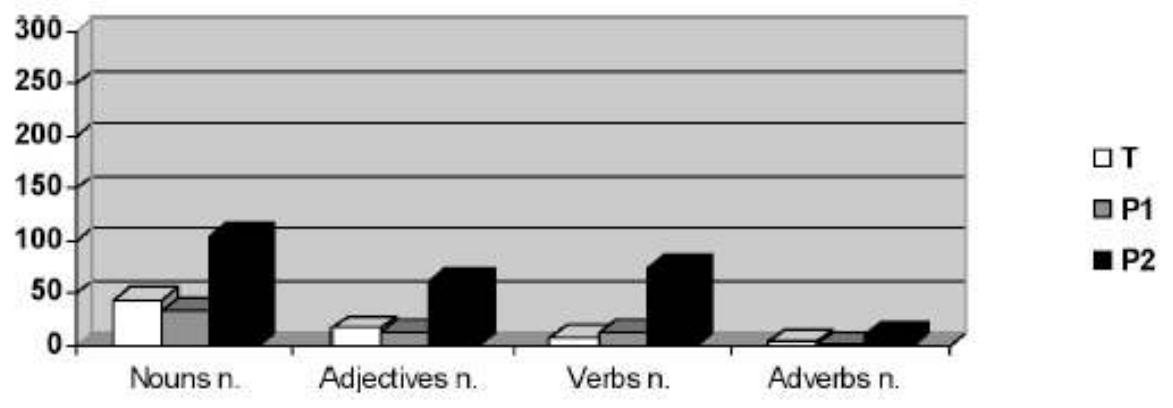

18 As we can see in Table 4 and Figure 4, among the 387 FF lexemes identified in the corpus, the number of adjectives and verbs was similar, while there were about twice as many nouns, and only a few adverbs. With regard to the three types of FF, nouns accounted for roughly a $60 \%$ of the total number of FF lexemes.

Table 5. Distribution of FF types in word classes (number of occurrences)

\begin{tabular}{|l|l|l|l|l|}
\hline FF & Nouns occ. & Adjectives occ. & Verbs occ. & Adverbs occ. \\
\hline T & $764(26.59 \%)$ & $149(18.30 \%)$ & $48(4.55 \%)$ & $21(42.85 \%)$ \\
\hline P1 & $322(11.20 \%)$ & $214(26.28 \%)$ & $190(18.04 \%)$ & $4(8.16 \%)$ \\
\hline P2 & $1787(62.19 \%)$ & $451(55.40 \%)$ & $815(77.39 \%)$ & $24(48.97 \%)$ \\
\hline FINAL NUMBER & $2,873(100 \%)$ & $814(100 \%)$ & $1,053(100 \%)$ & $49(100 \%)$ \\
\hline
\end{tabular}

Figure 5. Distribution of FF types in word classes (number of occurrences)

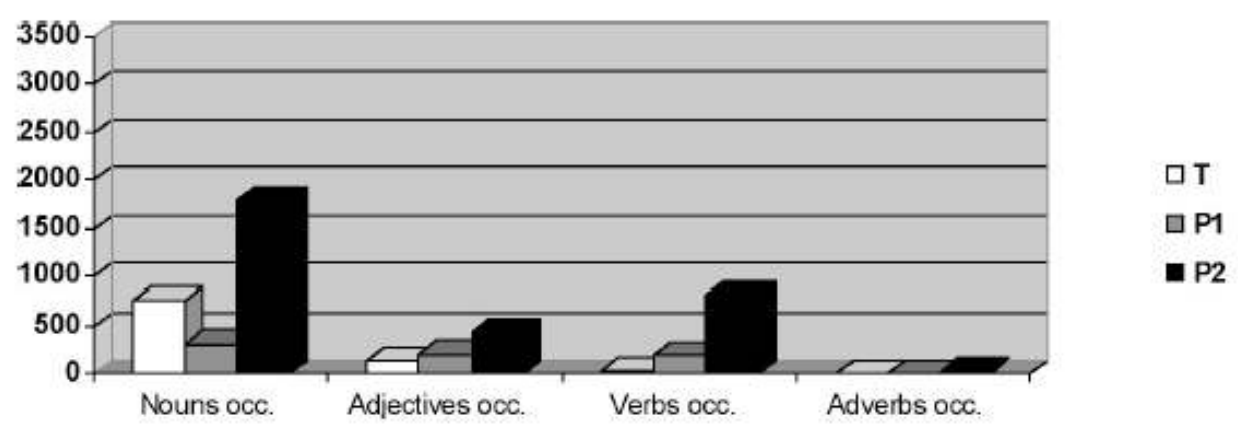

19 As can be seen in Table 5 and Graph 5, among the 4,789 FF occurrences found in the corpus, the number of adjectives and verbs was similar, while there were almost three times as many nouns, and again only a few adverbs. Considering the different types of FF, nouns accounted for almost a $60 \%$ of the total number of FF occurrences. A list of some examples of T, P1, and P2FF, including the four word classes analysed in this research, is provided below. Appendix 2 presents all the data in detail (Distribution of FF types in word classes in relation to the number of lexemes and occurrences). 
Table 6. Example of list of false friends

\begin{tabular}{|c|c|c|c|}
\hline English & Spanish & while Spanish & English \\
\hline \multicolumn{4}{|l|}{ Nouns } \\
\hline influenza & gripe & INFLUENCIA & influence \\
\hline injury & lesión herida, traumatismo, daño & INJURIA & $\begin{array}{l}\text { insult,offence, } \\
\text { slanderous allegation }\end{array}$ \\
\hline parent & progenitor & PARIENTE & relative \\
\hline physician & médico & FÍ́sICO & physicist \\
\hline \multicolumn{4}{|l|}{ Adjectives } \\
\hline actual & $\begin{array}{l}\text { real, verdadero, efectivo, concreto, } \\
\text { propiamente dicho }\end{array}$ & ACTUAL & present, current \\
\hline major & importante, principal, grave, serio & MAYOR & $\begin{array}{l}\text { greater, larger, bigger, } \\
\text { older }\end{array}$ \\
\hline consistent & constante, coherente, indicativo & CONSISTENTE & solid, sound, firm \\
\hline eventual & final, definitivo, permanente & EVENTUAL & $\begin{array}{l}\text { possible, casual, } \\
\text { temporary }\end{array}$ \\
\hline \multicolumn{4}{|l|}{ Verbs } \\
\hline to remove & extirpar, quitar, sacar, extraer & REMOVER & to stir, bring up again \\
\hline to stretch & extender, estirar, forzar & ESTRECHAR & to make (...) narrower \\
\hline to rest & descansar & RESTAR & to subtract, deduct \\
\hline to record & anotar, registrar & RECORDAR & to remember, remind \\
\hline \multicolumn{4}{|l|}{ Adverbs } \\
\hline ultimately & $\begin{array}{l}\text { en última instancia, finalmente, } \\
\text { llegado el momento, en el fondo }\end{array}$ & ULTIMAMENTE & recently, lately \\
\hline currently & actualmente, hoy en día & CORRIENTEMENTE & ordinarily \\
\hline
\end{tabular}

Table 7. Examples of P1FF collected in the sample

We present in capital letters the Spanish cognate that the inexperienced translator is most likely to use instead of the correct word in a particular context. 


\begin{tabular}{|c|c|}
\hline English & Spanish \\
\hline Nouns & \\
\hline canal & CANAL/ conducto (tubular structure) \\
\hline catheter & CATÉTER / sonda / drena \\
\hline condition & CONDICIÓN / afección, enfermedad, proceso \\
\hline disorder & DESORDEN / enfermedad, trastorno \\
\hline lens & LENTE / cristalino \\
\hline relative & RELATIVO / pariente, familiar \\
\hline Adjectives & \\
\hline adequate & ADECUADO / suficiente \\
\hline clinical & CLÍNICO / frío or aséptico (unemotional) \\
\hline domestic & DOMÉSTICO / local or nacional \\
\hline dramatic & DRAMÁTICO / espectacular / drástico \\
\hline aggressive & AGRESIVO / dinámico, audaz / traumático \\
\hline apparent & APARENTE / claro, notorio, evidente \\
\hline Verbs & \\
\hline to alter & ALTERAR, cambiar / castrar \\
\hline to compose & COMPONER / calmarse, sosegarse, tranquilizarse \\
\hline to discharge & DESCARGAR / dar de alta (from hospital) / supurar /despedir \\
\hline to prevent & PREVENIR / impedir, evitar \\
\hline Adverbs & \\
\hline adequately & ADECUADAMENTE / suficientemente \\
\hline evidently & EVIDENTEMENTE /al parecer, por lo visto \\
\hline
\end{tabular}

21 We present in capital letters the word that the inexperienced translator is most likely to use to the detriment of other terms (also capitalized in our examples and taken from Navarro 2000) which would be more appropriate. 
Table 8. Examples of P2FF identified in the corpus

\begin{tabular}{|c|c|}
\hline English & Spanish \\
\hline \multicolumn{2}{|l|}{ Nouns } \\
\hline test & TEST \\
\hline Apgar test & ÍNDICE de... \\
\hline blood test & ANÁLISIS de... \\
\hline diagnostic test & PRUEBA de... \\
\hline vaginal smear test & CITOLOGÍA... \\
\hline control & CONTROL \\
\hline birth control & ANTICONCEPCIÓN \\
\hline malaria control & LUCHA... \\
\hline self-control & AUTODOMINIO \\
\hline control of symptoms & SUPRESIÓN ... \\
\hline control visit & DE REVISIÓN \\
\hline control of an epidemic & CONTENCIÓN ... \\
\hline control group & ... DE REFERENCIA \\
\hline tract & TRACTO \\
\hline digestive tract & TUBO... \\
\hline auditory tract & VÍAS... \\
\hline genital male tract & APARATO... \\
\hline olfatory tract & CINTILLA or PÉNDULO... \\
\hline outflow tract & ...INFUNDÍBULO (of left ventricle) \\
\hline posterior tracts & CORDONES... \\
\hline rubrospinal tract & HAZ... \\
\hline \multicolumn{2}{|l|}{ Adjectives } \\
\hline established & ESTABLECIDO \\
\hline established custom & ...ARRAIGADA \\
\hline
\end{tabular}




\begin{tabular}{|c|c|}
\hline established diagnosis & ... DE CERTEZA \\
\hline established fact & ...ADMITIDO or DEMOSTRADO \\
\hline established staff & ...FIJO or DE PLANTILLA \\
\hline established use & ...CONSAGRADO \\
\hline established name & ...OFICIAL \\
\hline mental & MENTAL \\
\hline mental ability / work & ...INTELECTUAL \\
\hline mental clarity & GRADO DE DE LUCIDEZ or CONSCIENCIA \\
\hline mental stress & ...PSÍQUICA, NERVIOSA \\
\hline mental hospital & ...PSIQUIÁTRICO, MANICOMIO \\
\hline mental medicine & PSIQUIATRÍA \\
\hline systemic & SISTÉMICO \\
\hline systemic circulation & ...GENERAL or MAYOR \\
\hline systemic disease & ...GENERALIZADA \\
\hline systemic infection & ...DISEMINADA \\
\hline systemic vascular resistance & ...PERIFÉRICA \\
\hline \multicolumn{2}{|l|}{ Verbs } \\
\hline to check & CHEQUEAR \\
\hline to check a hemorrage & DETENER... \\
\hline to check an epidemic & CONTENER... \\
\hline to check blood & ANALIZAR... \\
\hline to check the results & VERIFICAR, COMPROBAR... \\
\hline to control & CONTROLAR \\
\hline to control a hemorrage & DETENER, RESTAÑAR... \\
\hline to control the blood pressure & MEDIR, VIGILAR, ESTABILIZAR... \\
\hline $\begin{array}{l}\text { to control the effects of an } \\
\text { overdose }\end{array}$ & NEUTRALIZAR... \\
\hline
\end{tabular}




\begin{tabular}{|l|l|}
\hline to control the temperature & REGULAR... \\
\hline to control the anemia & CORREGIR... \\
\hline to control a crisis & YUGULAR... \\
\hline Adverbs & ENTERAMENTE, totalmente, exclusivamente, unicamente \\
\hline entirely & $\begin{array}{l}\text { PRECISAMENTE, con precisión, } \\
\text { minuciosamente }\end{array}$ \\
\hline precisely &
\end{tabular}

\section{Discussion and conclusion}

As was expected, some FF are also found in General English. Differentiation of deceptive cognates into P1 and P2 categories has not been an easy task, and we found many borderline instances, a conclusion also reached by other researchers (Gläser 1995). From the previously detailed data one can draw general conclusions about the importance of the different FF types and their relevance according to the word classes. Firstly, FF of the $\mathrm{T}$ and $\mathrm{P} 1$ types can be expected to be the least common in the biomedical research written discourse (in our corpus, 982 and 730 occurrences respectively of the 4,789 instances found). However, students' or readers' overlooking them may have serious consequences for the correct interpretation of the source language text (they usually consist in meaning transgressions). Secondly, although the kind of mistake caused by the misunderstanding of P2FF instances may be much more a kind of inaccuracy (generally misunderstanding of very subtle nuances), its effect may cause a progressive erosion and impoverishment of the target language, and much more so if we consider their much greater frequency $(3,077$ occurrences in the sample). Therefore, we need to be on the alert for misleading collocations. Thirdly, nouns ranked first in all the frequency lists (close to $60 \%$ of the total number of FF occurrences were nouns), followed by adjectives and verbs with a similar distribution, except for the cases of P2 (in which verbs considerably outnumbered adjectives) and $\mathrm{T}$ lexemes (in which the opposite holds true). Therefore, regarding word classes, a representative FF reference list for pedagogical purposes should only include a very limited number of adverbs (just 49 occurrences in 89,688 running words), its major goal being the noun class.

Our findings differ slightly from those of the technical texts analyzed by Lerchundi \& Moreno (1999), for whom the most frequent kind of FF was the P1 type (in their work, falsos amigos 2), closely followed by TFF (falsos amigos 1). On the other hand, in their study, P2FF (falsos amigos 3) were the least frequent ones, while in ours the opposite held true. The results of Gläser's analysis (1995), based on a corpus of ESP text-books from a variety of fields, show a word class distribution quite similar to ours: nouns ranked first, with little difference in the number of verbs and adjectives.

The results of our analysis lead us to believe that deceptive cognates deserve careful consideration in the teaching of EMP to postgraduates and medical students as well as in the training of technical translators. This is of paramount importance in the Spanish 
scientist's case if we take into account that for the last thirty years a great proportion of biomedical Spanish literature has been the product of translations from English, frequently considered quite inadequate (Herranz 1984, Tapia 1991, Navarro \& Hernández 1992), false cognates being one of the most common kinds of mistake. Although it is practically impossible to indicate every single source of error, we suggest that more attention should be paid to them in academic syllabi.

It is thus our contention that some reference tables with the most frequent word pairs and their equivalent, together with well-chosen exercises to practise them, could be of great help if offered at early stages of reading comprehension and translation courses. They may increase the trainees' - and their teachers' - awareness of this complex and pervasive problem. The results obtained with some exercises we have designed consisting of identification and translation of contextualized FF are encouraging. In conclusion, similar studies based on other Romance languages could be of interest for the subsequent comparison of results.

\section{BIBLIOGRAPHY}

Congost Maestre Nereida. 1994. Problemas de la traducción técnica. Los textos médicos en inglés. Alicante: Universidad.

Divasson, Lourdes. 1997. “Deceptive cognates. Amistades peligrosas en Inglés Médico”. In Piqué J. \& J-V. Andreu-Besó (eds.), Lingüística aplicada en su contexto académico. Valencia: NAU Libres.

Gläser, Rosemarie. 1995. "False friends in LSP vocabulary with special reference to foreign language teaching”. In Laurén, Christer \& Marianne Nordman (eds.), Linguistic Features and Genre profiles of Scientific English. Frankfurt: Peter Lang, 15-26.

Herranz, G. 1984. “Ese acento extranjero”. Medicina Clínica 82, 162-163.

Hill, Robert R. 1982. A Dictionary of False Friends. London: Meeds.

Larson, Mildred L. 1989. La Traducción basada en el significado. Translated into Spanish by D. Burns and R. Von Moltke. Buenos Aires: Editorial universitaria.

Laufer, Batia. 1990. "Words you know: how they affect words you learn”. In Fisiak J. (ed.), Further insights into contrastive analysis. Amsterdam: John Benjamins, 573-593.

Lerchundi, María Ángeles \& Paloma Moreno. 1999. "Los falsos amigos en los textos técnicos”. In Ana Bocanegra Valle et al. (eds.), Enfoques teóricos y prácticos de las lenguas aplicadas a las ciencias y a las tecnologías. Cádiz: Universidad de Cádiz, 309-312.

Mackin, R. \& A. Weinberger. 1970. El Inglés para Médicos y Estudiantes de Medicina. London: Longman.

Maillot, Jean. 1997. La traducción científica y técnica. Translated into Spanish by Julia Sevilla. Madrid: Gredos.

Moss, Gillian. 1991. "Cognate recognition: Its importance in teaching ESP reading courses to Spanish speakers". English for Specific Purposes 11, 141-158. 
Mounin, G. et al. 1974. Dictionaire de la linguistique. Paris: P.U.F.

Navarro, F.A. \& F. Hernández. 1992. "Palabras de traducción engañosa en el inglés medico." Medicina Clínica 99, 575-580.

Navarro, F.A. \& F. Hernández. 1994. "Nuevo listado de palabras de traducción engañosa en el inglés medico”. Medicina Clínica 102, 142-149.

Platt, Jack, John Richards \& Heidi Weber. 1985. Longman Dictionary of Applied Linguistics. Harlow: Longman.

Robert-Collins Dictionnaire français-anglais, anglais-français. 1990. Paris: Le Robert; Glasgow: Collins. Ruiz Torres, Francisco. 1989. Diccionario de Términos Médicos (inglés-español, español-inglés). Madrid: Alhambra.

Smith Kline \& French Sae (eds.). 1979. Curso de Inglés Médico. Madrid: Gráficas ENAR.

Tapia, J. A. 1991. "La expresión inglesa halflife: una fuente de problemas en la literatura médica en castellano". Medicina Clínica 96, 103-105.

Webster's Ninth New Collegiate Dictionary. 1987. Springfield, MA: Merriam-Webster.

\section{Dictionaries}

Collins Cobuild English Language Dictionary. 1986. Edinburgh: Chambers.

Cuenca, M. 1987. Diccionario de términos equívocos (“falsos amigos"). Inglés-Español-Inglés. Madrid: Alhambra.

Diccionario de la Lengua Española. Real Academia Española (22nd edition). 2001. Madrid: Espasa Calpe. Diccionario enciclopédico University de términos medicos. 1981. México: Interamericana.

Diccionario Oxford. Español-Inglés, Inglés-Español (2nd edition). 1998. Madrid: Oxford University Press.

Dictionary-Glossary of Medical Terminology (English-Spanish). Diccionario-Glosario de Terminología Médica (Inglés-Español). 1981. USA: J. Xara Marrase.

Navarro, F. A. 2000. Diccionario crítico de dudas inglés-español de medicina. Madrid: McGraw-Hill Interamericana.

Stedman Bilingüe: Diccionario de Ciencias Médicas. Inglés- Español, Español-Inglés. 1999. Baltimore, MD: Lippincott Williams and Wilkins.

Stedman's Medical Dictionary (25th edition). 1990. Baltimore, MD: Williams \& Wilkins.

\section{APPENDIXES}

\section{Appendix 1. List of Corpus References}

Benedetti, J., L. Corey and R. Ashley. 1994. "Recurrence rates in genital herpes after symptomatic first-episode infection”. Annals of Internal Medicine 121/11, 847-854.

Boven, H.H. Van, R.J. Olds, S.L. Thein, P.H. Reitsma, D.A. Lane, E. Briët, J.P. Vandenbroucke and T.F.R. Rosendaal. 1994. "Hereditary antithrombin deficiency: Heterogeneity of the molecular basis and mortality in Dutch families". Blood 84, 12, 4209-4213. 
Case, C.P., V.G. Langkamer, C. James, M.R. Palmer, A.J. Kemp, P.F. Heap and L. Solomon. 1994. "Widespread dissemination of metal debris from implants". The Journal of Bone and Joint Surgery 76/B.5, 701-12.

Charabi, S., L. Illinken, M. Tos and J. Thomsen. 1994. "Histopathology and growth pattern of cystic acoustic neuromas". Laryngoscope 104/11, 1348-1352.

Christian, T.F., T.D. Miller, K.R. Bailey and R.J. Gibbons. 1994. "Exercise tomographic thallium-201 imaging in patients with severe coronary artery disease and normal electrocardiograms". Annals of Internal Medicine 121/11, 825-832.

Coffin, B., F. Azpiroz, F. Guarner and J.R. Malagelada. 1994. “Selective Gastric hypersensitivity and reflex hyporeactivity in functional dyspepsia”. Gastroenterology 107/5, 1345-1351.

Criqui, M.H. and B.L. Ringel. 1994. "Does diet or alcohol explain the French paradox?”. The Lancet 344, 1718-23.

Fergusson, D. M. and L.J. Horwood. 1994. "Nocturnal enuresis and behavioral problems in adolescence: A 15-Year longitudinal study”. Pediatrics 94/5, 662-668.

Gerberding, J.L. 1994. "Incidence and prevalence of Human Immunodeficiency Virus, hepatitis B Virus, hepatitis C virus, and cytomegalovirus among health care personnel at risk for blood exposure: Final report from a longitudinal study". The Journal of Infectious Diseases 170, 1410-1407.

Horowitz, M.J., C. Milbrath, M. Ewert, D. Sonneborn and C. Stinson. 1994. "Cyclical patterns of states of mind in psychotherapy". American Journal of Psychiatry 151/12, 1767-1770.

Lafon, M., D. Scott-Algara, P.N. Marche, P.A. Cazenave and E. Jouvin-Marchet. 1994. "Neonatal deletion and selective expansion of mouse $\mathrm{T}$ cells by exposure to rabies virus nucleocapsid superantigen”. Journal of Experimental Medicine 180, 1207-1215.

Lindheim, S.R., D.M. Duffy, T. Kojima, M.A. Vijod, F.Z. Stanczyk and R.A. Lobo. 1994. "The route of administration influences the effect of estrogen on insulin sensitivity in postmenopausal women". Fertility and Sterility 62/6, 1176-1180.

Litwin, M.S., R.D. Hays, A. Fink, P.A. Ganz, B. Leake, G.E. Leach and R.H. Brook. 1995. "Quality-of-life outcomes in men treated for localized prostate cancer". Journal of the American Medical Association 273/2, 129-135.

Mahajan, R.P., G.E. Murty, P. Singh and A.R. Aitkenhead. 1994. "Effect of topical anesthesia on the motor performance of vocal cords as assessed by tussometry". Anaesthesia 49, 1028-1030.

Mcaleese, P. and W. Odling-Smee. 1994. "The effect of complications on length of stay". Annals of Surgery 220/6, 740-744.

Meneilly, G.S., E. Cheung and H. Tuokko. 1994. "Counterregulatory hormone responses to hypoglycemia in the elderly patient with diabetes". Diabetes 43, 403-410.

Montagna, P., P. Cortelli Monari, G. Pierangeli, P. Parchi, R. Lodi, S. Iotti, C. Frassineti, P. Zaniol, E. Lugaresi and B. Barbiroli. 1994. “31P-Magnetic resonance spectroscopy in migraine without aura". Neurology 44, 666-669. 
Rosenfeld, B.A., N. Faraday, D. Campbell, K. Dise, W. Bell and P. Goldschmidt. 1994.

"Hemostatic effects of stress hormone infusion". Anesthesiology 81/5, 1116-1126.

Stanaland, B.E., E. Fernández-Caldas, C.M. Jacinto, W.L. Trudeau and R.F. Lockey. 1994.

"Sensitization to blomia tropicalis: Skin test and cross-reactivity studies". Journal of

Allergy and Clinical Immunology 94, 452-57.

Wheatley, H M., E.I. Traboulsi, B.E. Flowers, I.H. Maumenee, D. Azar, R.E. Pyerits and J.A. Whittum- Hudson. 1995. "Immunohistochemical localization of fibrillin in human ocular tissues relevance to the Marfan Syndrome”. Archives of Ophthalmology 113, 103-109.

\section{Appendix 2}

\section{Final Data of the Study - Table 1}

\begin{tabular}{|l|l|l|l|l|l|l|l|l|l|l|}
\hline FF & Nouns & $\begin{array}{l}\text { Nouns } \\
\text { occ. }\end{array}$ & Adjectives & $\begin{array}{l}\text { Adjectives } \\
\text { occ. }\end{array}$ & Verbs & $\begin{array}{l}\text { Verbs } \\
\text { occ. }\end{array}$ & Adverbs & $\begin{array}{l}\text { Adverbs } \\
\text { occ. }\end{array}$ & $\begin{array}{l}\text { Total } \\
\text { FF }\end{array}$ & $\begin{array}{l}\text { Total } \\
\text { occ. }\end{array}$ \\
\hline T & 44 & 764 & 17 & 149 & 8 & 48 & 4 & 21 & 73 & 982 \\
\hline P1 & 33 & 322 & 14 & 214 & 13 & 190 & 2 & 4 & 62 & 730 \\
\hline P2 & 105 & 1,787 & 61 & 451 & 75 & 815 & 11 & 24 & 252 & 3,077 \\
\hline Lexemes & 182 & 2,873 & 92 & 814 & 96 & 1,053 & 17 & 49 & 387 & 4,789 \\
\hline
\end{tabular}

Final Data of the Study - Table 2

\begin{tabular}{|l|l|l|l|l|}
\hline $\begin{array}{l}\text { WORD CLASS } \\
\text { followed by Occ }\end{array}$ & $\begin{array}{l}\text { TFF followed } \\
\text { by Occ }\end{array}$ & $\begin{array}{l}\text { P1FF followed } \\
\text { by Occ }\end{array}$ & $\begin{array}{l}\text { P2FF followed } \\
\text { by occ }\end{array}$ & $\begin{array}{l}\text { FF followed by } \\
\text { occ }\end{array}$ \\
\hline Nouns & 44 & 33 & 102 & 182 \\
\hline Nouns. Occ & 764 & 322 & 1,787 & 2,873 \\
\hline Adjectives & 17 & 14 & 61 & 92 \\
\hline Adjectives occ. & 149 & 214 & 451 & 814 \\
\hline Verbs & 8 & 13 & 75 & 96 \\
\hline Verbs occ. & 48 & 190 & 815 & 1,053 \\
\hline Adverbs & 4 & 2 & 11 & 17 \\
\hline Adverbs occ. & 21 & 4 & 24 & 497 \\
\hline Total FF & 73 & 730 & 3,077 & 489 \\
\hline Total occ. & 982 & & 252 & 49 \\
\hline
\end{tabular}




\section{ABSTRACTS}

"Faux amis" or "false friends" (abbreviated hereafter as FF) are metalinguistic terms used to name word pairs that look alike in two languages, but that do not have the same meaning. The purpose of this paper is to identify and classify FF in a corpus of medical English prose. Our source material consists of twenty research papers randomly chosen and published between 1994 and 1996 in various leading medical journals. Every FF was identified by means of a contextual analysis. The deceptive cognates recorded were classified according to two groups of variables: FF types and word classes. The proportion of FF found in the corpus reached $5.3 \%$ of the number of total running words. This leads us to believe that they deserve special attention since it is well known that they represent an important problem for terminologists and are frequently misinterpreted by medical doctors and students. We thus believe that the elaboration of tables containing word pairs (English-Spanish, in our case) most frequently encountered, along with well designed exercises, could prove most helpful if presented at an early stage of reading comprehension and translation courses.

L'expression «faux amis » (abrégée ci-dessous comme FA) est le terme métalinguistique utilisé pour se référer à des paires de mots qui s'écrivent presque de la même façon dans deux langues différentes mais qui ont un sens différent dans ces deux langues. Le but de cet article est d'identifier et de classifier les FA dans un corpus de vingt articles médicaux écrits en anglais, publiés entre 1994 et 1996 dans de prestigieuses revues médicales. Les FA ont été identifiés par une minutieuse analyse contextuelle, et ont été classifiés selon les deux variables suivantes: types et classes de FA. La fréquence de FA atteint 5,3\% du total de mots de notre corpus, ce qui nous conduit à penser qu'ils méritent une attention spéciale puisqu'il est reconnu qu'ils constituent un problème important pour les terminologues et sont très souvent mal interprétés par les médecins et les étudiants en médecine. Nous pensons donc qu'il serait très utile d'élaborer des tableaux de paires de FA (anglais-espagnol, dans notre cas) les plus fréquemment utilisés dans la littérature médicale de même que des exercices appropriés afin de les présenter aux étudiants au début des cours de lecture et/ou traduction scientifique.

\section{INDEX}

Mots-clés: analyse du discours, anglais de spécialité, anglais médical, faux ami (anglaisespagnol)

Keywords: deceptive cognate, discourse analysis, ESP, false friend (English-Spanish), medical English

\section{AUTHORS}

\section{LOURDES DIVASSON}

\section{ISABEL LEÓN}

